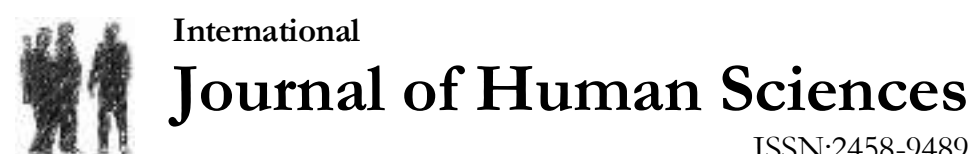

Volume 14 Issue 4 Year: 2017

\section{Nutritional habits and heart health of university students ${ }^{1}$}

\author{
Sidıka Oğuz ${ }^{2}$ \\ Nalan Çemçem ${ }^{3}$ \\ Gülşah Çamci ${ }^{4}$ \\ Aysel Gürkan ${ }^{5}$
}

\begin{abstract}
This study was performed to determine nutritional habits of the university students and to evaluate the nutritional habits according to the heart health. The research was performed in a cross-sectional and descriptive study between the students studying a university in Turkey between February 2015 -May 2015. A questionnaire was used a total of 32 questions for data collection. 602 voluntary students participated in the study. $69.3 \%$ of the students whose average of age were $20.04 \pm 1.87$ were female students and $63 \%$ of them were studying at the Faculty of Health Sciences. It was stated that breakfast was the most skipped meal and males had breakfast more than the female students $(\mathrm{p}=.001)$. Females consumed foods containing additives more than males $(\mathrm{p}<.05)$. Males consumed omega- 3 more than the females $(\mathrm{p}=.019)$. It was stated that females drank more milk than the males in the breakfast ( $\mathrm{p}=.044)$. Most of the male students added salt before tasting the foods $(\mathrm{p}=.001)$. Males drank more water than the females $(p=.003)$. It was detected that most of the females preferred whole wheat bread while most of the males preferred white bread in the meals $(\mathrm{p}=.001)$. It was found that the students consumed more the foods containing additives, consumed vegetable, fruit and fish little, added salt before tasting the foods and did not have breakfast regularly. According to these results, it was found that the nutritional habits of university students were not good according to the heart health.
\end{abstract}

Keywords: Nutrition; Student; Heart; Health; Omega-3.

\section{Introduction}

Nutrition has an important role for the health of the individual and the society. Primary aim of the individual and the society is to be healthy and productive. Human health is under the influence of nutrition, heredity, and environmental factors. Of these factors, nutrition is the most important one. A good nutrition is necessary for the health of all the individuals (Blotnicky, Mann, \& Joy,

\footnotetext{
${ }^{1}$ Oguz, S., Cemcem, N., Camci, G., \& Gurkan, A. (2016, April). Nutritional habits and heart health of the university students. European Journal of Cardiovascular Nursing 15 ( Supplement ):S84 (Poster)

2 Assoc. Prof. Dr., Marmara University Faculty of Health Sciences, Nursing Department of Internal Medicine, soguz@marmara.edu.tr

${ }^{3}$ MSc., Marmara University Faculty of Health Sciences, Nursing Department, camcigulsah@gmail.com

4 MSc., Marmara University Faculty of Health Sciences, Nursing Department of Internal Medicine, gulsah camci@,hotmail.com

5 Assoc. Prof. Dr., Marmara University Faculty of Health Sciences, Nursing Department of Surgical Medicine, agurkan@marmara.edu.tr
} 
2015:31; Mansoor, 2015:382). Globalization creates changes in the lifestyle and nutritional habits of the individual. Undernourishment and malnutrition lead to serious health problems such as cardiovascular diseases, hypertension, obesity, and osteoporosis (Laudanska-Krzeminska, 2012:163; Smeltzer et. al., 2008:69). Especially at early ages, it is necessary to provide sufficient nutrition in accordance with the requirement of the body. That the youth of university has healthy nutritional habits is important in terms of the society. This is because independent eating habit occurs upon leaving the house in this period (Baysal, 2011:5). Habits of the university students such as skipping breakfast, decreasing the daily number of meals, eating irregularly, alcohol consumption and smoking, insufficient fluid intake and low physical activity may negatively affect the mental and physical health of the students. Furthermore, this risk increases with the fast food consumption of the students instead of milk and dairy products, vegetable and fruit. This unhealthy nutrition of the university students may also pave the way for cardiovascular diseases (Alibabić et. al., 2014:2137).

Irazusta et al. (2007:387) detected in their study that nutritional habits of the first grade university students were poor. It was emphasized that poor nutritional habits were associated with increased risk factors for cardiovascular disease. In a study made by Laudanska-Krzeminska (2012:163) in 508 students at Poznan University, 30\% of the students were found to consume vegetable and fruit daily. In the study by Loomes and Croft (2013:483) and Alibabić et al., (2014:2137) fast food consumption of the university students were high. In the study by Van den Berg et al. (2012:1) in 161 nursing students in the South Africa, 20.5\% of the students were found to consume no fish at all.

Inadequate healthy nutrition information is also an important factor affecting the nutrition of the young. Inadequate nutrition information and negative economic conditions result in undernourishment and malnutrition of the young. Acquiring healthy nutritional habits by the university students is important in terms of the society (Vançelik, Önal, Güraksın, \& Beyhun, 2007:242). Solving the poor nutrition problems of the students can be achieved by providing them to realize and correct their wrong habits with the nutrition education to be given to them (Loomes $\&$ Croft, 2013:483).

University youth is the group under risk in terms of the prevalence of the nutrition problems. Through healthy nutrition, risk factors leading to coronary artery disease can be prevented. Preferring vegetable oil, reducing the consumption of salt and calorie amounts, and adopting a diet rich in fruit and vegetable will reduce the risk of cardiovascular disease and diseases secondary to nutrition problems (Singh et al., 2002:1455).

\section{Material and Method}

Aim

This study was performed a cross-sectional and descriptive study to determine nutritional habits of the university students and to evaluate the nutritional habits according to the heart health Place, time and sample of the research

The universe of research was composed the students studying at Health Sciences and Social Sciences Students of a university in Turkey between February 2015-May 2015. 602 voluntary students (379 students from health sciences and 223 students from social sciences) were included in the research.

\section{Data collection}

The questionnaire consists of a total of 32 questions for data collection, questions of the questionnaire were created according to the literature, 13 questions of which consist of sociodemographic questions (age, department, grade, educational background of the parents, etc.) and 19 questions of which consist of habits regarding the nutrition (how many meals do you have a day?, what is the meal that you skip a the most?, do you drink eight glass $(1600 \mathrm{ml})$ of water in a day?, do you consume five portions of vegetable-fruit in a day?, what kind of bread do you prefer?, etc.). The questionnaires were distributed to the students to class at the end of the lessons. The questionnaires were filled in about 10 minutes. 


\section{Statistical analysis}

Percentage, frequency, average and chi-square were used for the statistical analyses. Significance level was taken as $\mathrm{p}<.05$ in all of the tests.

\section{Ethical Aspect of the Research}

Written consent was obtained from university administrations (Protocol number: 02.2015.036). The individuals were informed about the objective of the research, verbal and written consent of them were taken. Since the personal rights are required to be protected, human rights Helsinki Declaration was abided by throughout the research.

\section{Results}

$63 \%$ of the students were studying in Health Sciences (Medicine, Nursing, Pharmacy, Anesthesia, etc.) while 37\% of them were studying in Social Sciences (Law, Faculty of Education, etc.). $69.3 \%$ of the students whose average of age were $20.04 \pm 1.87$ are female and $30.7 \%$ of them are male. $49.8 \%, 20.1 \%, 16.6 \%, 11.5 \%$, and $2 \%$ of the students were in the second grade, first grade, fourth grade, third grade, and fifth grade, respectively. $38.5 \%$ of the students were living in the dormitory, $33.6 \%$ of them were living with their family/relatives, $25.7 \%$ of them were living with their friends and $2.2 \%$ of them were living alone.

Table 1.Distribution of the Eating/Drinking Habits of the Students $(\mathrm{N}=602)$

\begin{tabular}{lcccc}
\hline Eating/Drinking Habits & \multicolumn{2}{c}{ Yes } & \multicolumn{2}{c}{ No } \\
\hline & $\mathbf{n}$ & $\mathbf{\%}$ & $\mathbf{n}$ & $\mathbf{\%}$ \\
Five Portions of Vegetable and Fruits & 55 & 9.1 & 547 & 90.9 \\
Omega-3 & 59 & 9.8 & 543 & 90.2 \\
Fish & 62 & 10.3 & 540 & 89.7 \\
Legumes & 78 & 13.0 & 524 & 87.0 \\
Milk & 170 & 28.2 & 432 & 71.8 \\
Adding Salt Before Tasting The Foods & 174 & 28.9 & 428 & 71.1 \\
Drinking Two Liters Of Water Daily & 329 & 54.7 & 273 & 45.3 \\
Boiled / GridPreference & 387 & 64.3 & 215 & 35.7 \\
Carbonated Beverages & 403 & 66.9 & 199 & 33.1 \\
Egg & 451 & 74.9 & 151 & 25.1 \\
Pastry, Cake & 464 & 77.1 & 138 & 22.7 \\
Foods Containing Additives & 468 & 77.7 & 134 & 22.3 \\
Caffeinated Beverage & 482 & 80 & 120 & 20 \\
\hline
\end{tabular}

$9.1 \%$ of the students consumed five portions of vegetable and fruits in a day, $9.8 \%$ of them consumed omega-3, 10.3\% of them ate fish at least twice a week, $13.0 \%$ of them consumed legumes, $28.2 \%$ of them drank milk in the breakfast, $28.9 \%$ of them added salt before tasting the foods, $54.7 \%$ of them drank two liters of water daily, $64.3 \%$ of them preferred boiled and grill food instead of frying, $66.9 \%$ of them consumed carbonated beverages, $74.9 \%$ of them consumed egg in the breakfast, $77.1 \%$ of them ate bagel, pastry, cake, etc. in the breakfast, $77.7 \%$ of them consumed foods containing additives and $80 \%$ of them drank caffeinated beverage (Table 1). 
Oğuz, S., Çemçem, N., Çamc1, G., \& Gürkan, A. (2017). Nutritional habits and heart health of university students. Journal of Human Sciences, 14(4), 3606-3614. doi:10.14687/jhs.v14i4.4871

Table 2.Comparison of the Consumption of the Food Containing Additives by the Students according to the Departments, Following the Nutrition and Heart Health News and Competence Status of the Public Service Announcements (N=602)

Variables

\begin{tabular}{cccc}
\multicolumn{2}{c}{ Department } & $\chi^{2}$ & $p$ \\
Health & Social & & \\
Sciences & Sciences & & \\
\cline { 1 - 2 } $\mathbf{n}(\%)$ & $\mathrm{n}(\%)$ &
\end{tabular}

\begin{tabular}{|c|c|c|c|c|c|}
\hline Consumption of the Food & Yes & $304(80.2)$ & $164(73.5)$ & 3.608 & .037 \\
\hline Containing Additives & No & $75(19.8)$ & $59(26.5)$ & & \\
\hline Following the Nutrition & Yes & $207(54.6)$ & $88(39.5)$ & 12.904 & .0001 \\
\hline and Heart Health News & No & $172(45.4)$ & $135(60.5)$ & & \\
\hline Competence Status of the & Yes & $36(47.4)$ & $343(65.2)$ & 9.063 & .002 \\
\hline Service & No & $40(52.6)$ & $183(34.8)$ & & \\
\hline
\end{tabular}

It was stated that students of Health Sciences consumed foods containing additives more than the students of Social Sciences $(\mathrm{p}=.037)$ and followed the news regarding the nutrition and heart health more than the same $(\mathrm{p}<.05)$. The students studying in the Health Sciences found the public service announcements made regarding the nutrition and heart health more insufficient $(\mathrm{p}=.002)$ (Table 2).

Table 3.Comparison of the Meals Skipped Mostly According to the Gender of the Students $(\mathrm{N}=602)$

\begin{tabular}{lllll}
\hline \multirow{2}{*}{ Meals Skipped Mostly } & \multicolumn{2}{c}{ Gender } & $\chi^{2}$ & $\mathbf{p}$ \\
\cline { 2 - 3 } Breakfast & $\begin{array}{l}\text { Female } \\
\mathbf{n}(\%)\end{array}$ & $\begin{array}{l}\text { Male } \\
\mathbf{n}(\%)\end{array}$ & & \\
Lunch & $184(44.2)$ & $112(60.5)$ & & \\
Diner & $196(47.0)$ & $65(35.2)$ & 14.733 & .001 \\
\hline
\end{tabular}

It was determined that breakfast was the most skipped meal and males had breakfast more than the female students ( $\mathrm{p}=.001)$ (Table 3).

Table 4.Comparison of the Bread Choice of the Students According to the Gender $(\mathrm{N}=602)$

\begin{tabular}{lcccc}
\hline Variables & \multicolumn{3}{c}{ Bread Choice } & \\
\hline & White Bread & Whole Wheat Bread & $\chi^{2}$ & $\mathbf{p}$ \\
& $\mathbf{n}(\%)$ & $\mathbf{n}(\%)$ & & \\
Female student & $256(61.4)$ & $161(38.6)$ & 11.657 & .001 \\
Male student & $140(75.7)$ & $45(24.3)$ & & \\
\hline
\end{tabular}

It was detected that most of the females preferred whole wheat bread while most of the males preferred white bread in the meals $(\mathrm{p}=.001)$ (Table 4). 
Oğuz, S., Çemçem, N., Çamc1, G., \& Gürkan, A. (2017). Nutritional habits and heart health of university students. Journal of Human Sciences, 14(4), 3606-3614. doi:10.14687/jhs.v14i4.4871

Table 5.Comparison of the Food and Beverages Consumed According to the Gender $(\mathrm{N}=602)$

\begin{tabular}{|c|c|c|c|c|c|c|}
\hline Food and & & male & & Iale & $\chi^{2}$ & $\mathrm{p}$ \\
\hline Beverages & Yes & No & Yes & No & & \\
\hline Consumed & $\mathrm{n}(\%)$ & $\mathrm{n}(\%)$ & $\mathrm{n}(\%)$ & $\mathrm{n}(\%)$ & & \\
\hline $\begin{array}{l}\text { Foods Containing } \\
\text { Additives }\end{array}$ & $347(83.2)$ & $70(16.8)$ & $121(65.4)$ & $64(34.6)$ & 23.485 & .0001 \\
\hline Omega-3 & 33 (7.9) & $384(92.1)$ & $26(14.1)$ & $159(85.9)$ & 5.466 & .019 \\
\hline $\begin{array}{l}\text { Drinking Milk At } \\
\text { Breakfast }\end{array}$ & $128(30.7)$ & $289(69.3)$ & $42(22.7)$ & $143(77.3)$ & 4.040 & .044 \\
\hline $\begin{array}{l}\text { Adding Salt Before } \\
\text { Tasting The Foods }\end{array}$ & $104(24.9)$ & $313(75.1)$ & $70(37.8)$ & $115(62.2)$ & 10.374 & .001 \\
\hline $\begin{array}{l}\text { Drinking Two } \\
\text { Liters Of Water } \\
\text { Daily }\end{array}$ & $211(50.6)$ & $206(49.4)$ & $118(63.7)$ & $67(36.3)$ & 8.988 & .003 \\
\hline
\end{tabular}

It was found that females consumed foods containing additives more than the males $(p<.05)$ and males consumed omega-3 more than the females $(p=.019)$. It was stated that females drank more milk than the males in the breakfast $(\mathrm{p}=.044)$. Most of the male students added salt before tasting the foods $(p=.001)$. Males drank more water than the females $(p=.003)$ (Table 5).

\section{Discussion}

It was found that $28.2 \%$ of the students drank milk in the breakfast (Table 1). Mazıcioğlu and Öztürk (2003:172) found that $40.1 \%$ of the university students didn't consume milk at all. In the study made by Amber Sayed (2012:36) in the university students in Pakistan, 14.6\% of them consumed milk 1-2 days a week, $24.6 \%$ of them consumed milk 3-5 days a week, $18.1 \%$ of them consumed milk 6-7 days a week and $42.7 \%$ of them didn't consume milk at all. In the study by Alibabić et al. (2014: 2137), consumption of milk and dairy products by the students was $26.3 \%$. In the study by Schnettler et al. (2015:203), 44.4\% of the students were found to consume milk and dairy products daily. In this study milk consumption was higher than in the above studies.

$87 \%$ of the students participating in the research consumed legumes, $10.3 \%$ of them ate fish at least twice a week and $74.9 \%$ of them consumed egg in the breakfast (Table 1). In the research by Aytekin (1999:35), 25\% of the university students didn't consume fish at all while those consuming fish consumed it very rarely, $66 \%$ of them consumed egg, $50.8 \%$ of them consumed legumes such as bean and chick pea. In the study by Irazusta et al. (2007: 387), cereal and bean consumption of the university students was little. Laudanska-Krzeminska (2012:163) stated that the most of the students at Poznan University rarely consumed legumes or didn't consume the same at all. In the study by Van den Berg et al. (2012: 1) in 161 nursing students in the South Africa, $20.5 \%$ of the students were found to consume no fish at all, $77.6 \%$ of them consumed fish every month, and $26.1 \%$ of them didn't consume cereal at all. In the study by Schnettler et al. (2015: 203), 57.5\% of the university students consumed cereal and cereal products. Findings of our study are similar to some of the studies above. Obtaining this result is thought to be based on the economic condition and nutritional habits of the countries. Low consumption of fish is similar to the general findings in our country.

It was detected that $77.7 \%$ of the students participating in this study consumed foods containing additives (Table 1). Al-Khamees (2009:499) determined that most of the university students used foods with protecting and coloring agents. In the study by Loomes and Croft (2013:483), fast food (23.1\%) (hamburger, pizza and chips) consumption of the university students were more than the consumption of snack food such as ice cream, biscuit, dried fruits and cake. In the study by Alibabić et al. (2014:2137), consumption of fast food by the students was $78.2 \%$. In 
Oğuz, S., Çemçem, N., Çamc1, G., \& Gürkan, A. (2017). Nutritional habits and heart health of university students. Journal of Human Sciences, 14(4), 3606-3614. doi:10.14687/jhs.v14i4.4871

the researches made students were observed to highly consume foods containing additives. We are of the opinion that it is especially because natural food is not sold in the canteens. Moreover, high saturated fat ratio in these products creates a risk for cardiovascular diseases.

$9.1 \%$ of the students in our study consumed five portions of vegetable and fruit daily (Table 1). A lot of studies were found that vegetable and fruit consumption of the university students was low (Lytle et al., 2003:170; Sakamaki, Toyama, Amamoto, Liu, \& Shinfuku, 2005:4; Yahia, Achkar, Abdallah, \& Rizk, 2008:1; Carmel \& Camilleri, 2011:2; Gazibara, Tepavcevic, Popovic, \& Pekmezovic, 2013: 330; Amankwaa \& Annan, 2014:18; Muñoz-Cano, CordovaHernandez, \& del Valle-Leveaga, 2014:1582). Our study was similar to other studies. Eating $200 \mathrm{~g}$ (2-3 portions) fruit daily and $200 \mathrm{~g}$ (2-3 portions) vegetable daily is recommended to be protected from cardiovascular diseases (Perk et al., 2012:1635). Daily vegetable and fruit intake of the students is low.

$54.7 \%$ of the students in our study drank two liters of water daily while $79.9 \%$ of them consumed caffeinated beverages (Table 1). In the research by Arslan and Mendess (2004:163), the most commonly consumed beverages by the university students were detected to be water and tea. Carmel and Camilleri (2011:2) showed that $84 \%$ of the students at university of Malta preferred to drink water. In the study by Özboy Özbaş et al. (2013:518), of the 74 fourth grade physical education students, 25 of them consumed three glasses of or less water, 32 of them consumed 4-6 glasses of water, and four students consumed 8-10 glasses of water. Water consumption in our study is higher than the water consumed by the students in the other studies.

In this study was found that breakfast was the most skipped meal and males had breakfast more than the females $(p=.001)$ (Table 3). A few studies were determined that breakfast was the most skipped meal (Heşeminia, Çalışkan, \& Işık, 2002:155; Laudanska-Krzeminska, 2012:163; Loomes \& Croft, 2013:483 ; Neslişah \& Emine, 2011:117; Sabaei, Sabaei, Mojtabavi, Ebrahimpour, \& Fallah-Rostami, 2015:14). Those who have breakfast daily are found to have a more favorable lipid profile and body mass index in the studies. Thus, skipping breakfast increases the risk of cardiovascular diseases (Hallström et al., 2013:1296; Morillas-Ruiz, 2014:71; Papoutsou et al., 2014:829). Inadequacy of time or economic opportunities can be considered as the reason for skipping meals.

In our research, females were detected to prefer whole wheat bread while males are detected to prefer white bread in the meals $(\mathrm{p}=.001)$ (Table 4). In the study by Brittin and Obeidat (2011:552), most of the university students were found to consume white bread and consumption of brown bread and whole wheat bread was low. In the study by Carmel and Camilleri (2011:2), while male students preferred to eat white bread females preferred to eat whole wheat bread. In the study by Suliga et al. (2012:98) in 697 female university students, $49.6 \%$ of them consumed white bread daily while $29.1 \%$ of them consumed whole wheat bread daily. Amber Sayed (2012: 36) found that $24.2 \%$ of the students had whole wheat food $1-2$ days a week, $23.8 \%$ of them had whole wheat food 3-5 days a week, $23.8 \%$ of them had whole wheat food 6-7 days a week and $28.1 \%$ of them didn't consume whole wheat food in a week at all. Laudanska-Krzeminska (2012:163) stated that fewer than the half of the students ate whole wheat products daily. In a research made by Aksoylu et al. (2014:147), females consumed less bread than the males, as well as, females preferred whole wheat bread more than the males. In the study by Van den Berg et al. (2012:1), 55.9\% of the students were found to consume bread daily. In the study made by Schnettler et al. (2015:203), 74\% of the students were observed to consume bread daily. Our study was similar to the studies above.

It was stated that female students drank more milk than the male students in the breakfast $(p=.044)$. Female students consumed foods containing additives more than the male students $(\mathrm{p}<.05)$. Males consumed omega-3 more than the females $(\mathrm{p}=.019)$. Most of the male students added salt before tasting the foods $(\mathrm{p}=.001)$. Male students drank more water than the females $(\mathrm{p}=.003)$ (Table 5). Looking at the literature, it was stated that university students of this age group should consume about three liters of water daily (Köksal \& Özel, 2008:7), but the consumption of carbonated beverages, instant fruit juice gets ahead of the beverages such as water, milk and 
buttermilk ( Ball, Bindler and Cowen,2010:100; Morse \& Driskell, 2009:173). Studies showed that the students consumed little water, daily need, and the rate of those who consumed coffee, coke and tea daily is substantial. In another research made with the students of 19 and 24 years of age, fast food consumption of the male students was higher than the female students (Morse \& Driskell, 2009:173). In the study by Amber Sayed (2012: 36), 18.8\% of the students added salt to the food one-two times a week, $14.2 \%$ of them added salt three to five times a week, $28.5 \%$ of them added salt six-seven times a week, $38.5 \%$ of them didn't add salt to the food at all. In the study SALTURK (2011) made in Turkey, salt consumption was determined as $18.04 \pm 8.34 \mathrm{~g}$ on average for the entire group. World Health Organization recommends taking five grams of or less salt daily. Projects are performed to achieve this target in our country. In the studies made in different countries, daily salt consumption was determined as nine grams on average in Finland, nine grams on average in England, and 10 grams on average in Italy. The differences in food choices of the individuals included in the sample on which the research was conducted may result from the cultural differences.

According to the European guide for protection from cardiovascular diseases in the clinical practice, unsaturated fats should be consumed instead of the saturated fats, and saturated fatty acids should constitute $<10 \%$ of total energy intake. Daily salt intake should be $<5 \mathrm{~g}$. Daily fiber intakes should be $35-40 \mathrm{~g}$, should be supplied from whole wheat products, fruit and vegetables. $200 \mathrm{~g}$ (2-3 portions) fruit and $200 \mathrm{~g}$ (2-3 portions) vegetable should be eaten daily. Fish should be consumed at least twice a week (Perk et al., 2012:1635).

\section{Conclusion}

It was found that the students consumed more the foods containing additives, consumed vegetable, fruit and fish little, added salt before tasting the foods and did not have breakfast regularly. According to these results, it was found that the nutritional habits of university students were not good according to the heart health.

Acknowledgments The authors would like to thank the participants of the study.

Funding No funding was received for this project.

Conflict of interest All authors declare that they have no competing interests.

\section{References}

Aksoylu, Z., Savlak, N. Y., Yanğıç, Ç., Çağındı, Ö., \& Köse, E. (2014). Manisa il merkezinde bireylerin ekmek çeşitlerini tüketim alışkanlıklarının belirlenmesi. Gıda Dergisi, 39(3):14754.

Alibabić, V., Mujić, I., Rudić, D., Golob, M., Šertović, E., Bajramović, M., \& Jokić, S. (2014). Assessment of Diet Quality and Nutritional Risks Representation of University of Bihać. Procedia-Social and Behavioral Sciences, 116, 2137-2140.

Al-Khamees, N. A. (2009). Food habits of university nutrition students: pilot study. Nutrition \& Food Science, 39(5):499-502. doi:10.1108/00346650910992150

Amankwaa, A., \& Annan, R. (2014). Dietary patterns and metabolic risk factors for cardiovascular disease among University Students in Ghana. Asian J Clin Nutr, 6(1):1828.

Amber Sayed, S. (2012). cross-sectional study on eating habits and food related beliefs and knowledge in university students of Karachi, Pakistan. Pak J Public Health, 2(2):36-42.

Arslan, C., \& Mendeş, B. (2004). Üniversitelerin farklı bölümlerinde okuyan erkek ve k1z öğrencilerin sıvı tüketimleri ve bilgi düzeylerinin araştırılması. Fırat Üniversitesi Sağlık Bilimleri Dergisi, 18(3): 163-170.

Aytekin, F. (1999). Üniversite öğrencilerine verilecek beslenme eğitiminin beslenme davranışlarına olan etkisinin incelenmesi. Gazi Üniversitesi, Sosyal Bilimler Enstitüsü, Doktora Tezi, Ankara.p:35 
Oğuz, S., Çemçem, N., Çamc1, G., \& Gürkan, A. (2017). Nutritional habits and heart health of university students. Journal of Human Sciences, 14(4), 3606-3614. doi:10.14687/ihs.v14i4.4871

Ball, J.W., Bindler, R.C., Cowen, K.J. (2010). Child Health Nursing Partnering with Children \& Families. Co Pearson Education, Second Edition, New Jersey, p.100.

Baysal, A. (2011).Beslenme. 13'üncü bask1, Hatiboğlu Yayınevi, Ankara. p. 5-20

Blotnicky, K. A., Mann, L. L., \& Joy, P. R. (2015). An assessment of university students' healthy eating behaviors with the expectancy theory, ASBBS Ejournal 11(1):31.

Brittin, H. C., \& Obeidat, B. A. (2011). Food practices, changes, preferences and acculturation of Arab students in US universities. International Journal of Consumer Studies, 35(5): 552 559. doi: 10.1111/j.1470-6431.2011.01023.x

Carmel , C., Camilleri, L. (2011).The dietary habits of Maltese university students. Malta Medical Journal , 23:2.

Gazibara, T., Tepavcevic, D. B. K., Popovic, A., \& Pekmezovic, T. (2013). Eating habits and body-weights of students of the University of Belgrade, Serbia: a cross-sectional study. Journal of health, population, and nutrition, 31(3):330.

Hallström, L., Labayen, I., Ruiz, J. R., Patterson, E., Vereecken, C. A., Breidenassel, C., . . . Mistura, L. (2013). Breakfast consumption and CVD risk factors in European adolescents: the HELENA (Healthy Lifestyle in Europe by Nutrition in Adolescence) Study. Public health nutrition, 16(07):1296-1305.

Heşeminia, T., Çalışkan, D., \& Işık, A. (2002). Ankara'da yüksek öğretim öğrenci yurtlarında kalan öğrencilerin beslenme sorunları. İbni Sina Tip Dergisi, 7:155-166.

Irazusta, A., Hoyos, I., Irazusta, J., Ruiz, F., Díaz, E., \& Gil, J. (2007). Increased cardiovascular risk associated with poor nutritional habits in first-year university students. Nutrition Research, 27(7):387-394. doi: 10.1016/j.nutres.2007.05.007.

Köksal, G., \& Özel, G. (2008). Çocukluk ve Ergenlik Döneminde Obezite. Sağlık Bakanlığı, Birinci Bask1. Ankara: Klasmat Matbaacilık, p. 7-13.

Laudanska-Krzeminska, I. (2012). Dietary behaviour of students from Poznan universities. Papers on Anthropology, 21: 163-175.

Loomes, S., \& Croft, A. (2013). An investigation into the eating behaviour of international students studying at an Australian university: should we be concerned? Journal of Higher Education Policy and Management, 35(5): 483-494. Doi:10.1080/1360080X.2013.825418

Lytle, L. A., Varnell, S., Murray, D. M., Story, M., Perry, C., Birnbaum, A. S., \& Kubik, M. Y. (2003). Predicting adolescents' intake of fruits and vegetables. Journal of Nutrition Education and Behavior, 35(4):170-178.

Mansoor, S. (2015). Nutrition education curriculum for training physicians in medical colleges of Pakistan. Pak Armed Forces Med J 65(3):382-85.

Mazicioglu, M., \& Ozturk, A. (2003). Üniversite 3. ve 4. sinıf öğrencilerinde beslenme alışkanlıkları ve bunu etkileyen faktörler, Erciyes Tıp Dergisi (Erciyes Medical Journal), 25 (4): $172-8$

Morse, K. L., \& Driskell, J. A. (2009). Observed sex differences in fast-food consumption and nutrition self-assessments and beliefs of college students. Nutrition Research, 29(3), 173179. doi: 10.1016/j.nutres.2009.02.004

Morillas-Ruiz, J.M .(2014). Relationship between quality of fat consumed at breakfast and cardiovascular risk:Review. Nutr Hosp, 30(2):71-73.

Muñoz-Cano, J., Cordova-Hernandez, J., \& del Valle-Leveaga, D. (2014). The healthy eating index of new students at an university of Mexico. Nutricion hospitalaria, 31(4):1582-1588. doi: 10.3305/nh.2015.31.4.8401

Neslişah, R., \& Emine, A. Y. (2011). Energy and nutrient intake and food patterns among Turkish university students. Nutrition research and practice, 5(2): 117-123.

Ozbas, O. O., Arslan, F., Suel, E., \& Sahin, I. (2013). Comparison of the nutritional habits of the students at the first and fourth classes in the physical education and sport training department of Aksaray University. Science, Movement and Health, 13 (2):518-24. 

Journal of Human Sciences, 14(4), 3606-3614. doi:10.14687/jhs.v14i4.4871

Papoutsou, S., Briassoulis, G., Wolters, M., Peplies, J., Iacoviello, L., Eiben, G., . . . Michels, N. (2014). No breakfast at home: association with cardiovascular disease risk factors in childhood. European journal of clinical nutrition, 68(7):829-834.

Perk, J., De Backer, G., Gohlke, H., Graham, I., Reiner, Ž., Verschuren, M., . . . Cifkova, R. (2012). European Guidelines on cardiovascular disease prevention in clinical practice (version 2012). European heart journal, 33(13), 1635-1701.

Sabaei, S., Sabaei, Y., Mojtabavi, S., Ebrahimpour, S., \& Fallah-Rostami, F. (2015). The Prevalence of obesity and 1ts relation to physical activity and dietary patterns among Female High School Students of Tehran, Iran. Crescent Journal of Medical and Biological Sciences, 2(1):14-17.

Sakamaki, R., Toyama, K., Amamoto, R., Liu, C.-J., \& Shinfuku, N. (2005). Nutritional knowledge, food habits and health attitude of Chinese university students-a cross sectional study-. Nutrition journal, 4(1):4. doi:10.1186/1475-2891-4-4

SALTURK (2011) T.C. Ministry of Health, General Directorate of Primary Health Care, Department of Nutrition and Physical Activity (2011) Reduction program of excessive salt consumption in Turkey 2011-2015-SALTURK. First edition, the 2011-2015 program. Ankara, Deniz Printing. .

Schnettler, B., Miranda, H., Lobos, G., Orellana, L., Sepúlveda, J., Denegri, M., . . . Grunert, K. G. (2015). Eating habits and subjective well-being. A typology of students in Chilean state universities. Appetite, 89:203-214. doi:10.1016/j.appet.2015.02.008

Singh, R. B., Dubnov, G., Niaz, M. A., Ghosh, S., Singh, R., Rastogi, S. S., . . . Berry, E. M. (2002). Effect of an Indo-Mediterranean diet on progression of coronary artery disease in high risk patients (Indo-Mediterranean Diet Heart Study): a randomised single-blind trial. The Lancet, 360(9344), 1455-1461. doi:10.1016/S1062-1458(03)00048-5

Smeltzer, S., Bare, B., Hinkle, J., Cheever, K., Townsend, M. C., \& Gould, B. (2008). Brunner \& Suddarth's Textbook of Medical Surgical Nursing 12th Edition: Wolters Kluwer: Lippincott Williams and Wilkins. 12e2009/ 68 pp./ 750 illus./ 978-0-7817-8589.p:69-74.

Suliga, E., Wronka, I., \& Pawlińska-Chmara, R. (2012). Nutritional habits of female university students in relation to selfperception of body. Biomedical Human Kinetics, 4:98-102. doi: 10.2478/v10101-012-0018-9.

Van den Berg, V. L., Okeyo, A. P., Dannhauser, A., \& Nel, M. (2012). Body weight, eating practices and nutritional knowledge amongst university nursing students, Eastern Cape, South Africa: original research. African Journal of Primary Health Care and Family Medicine: 4(1), 1-9. doi: 10.4102/phcfm.v4i1.323

Vançelik, S., Önal, S. G., Güraksın, A., \& Beyhun, E. (2007). Üniversite öğrencilerinin beslenme bilgi ve alışkanlıkları ile ilişkili faktörler. TSK Koruyucu Hekimlik Bülteni, 6(4):242-248.

Yahia, N., Achkar, A., Abdallah, A., \& Rizk, S. (2008). Eating habits and obesity among Lebanese university students. Nutrition journal, 7(32):1-6. doi:10.1186/1475-2891-7-32 